\title{
Perbandingan antara Penggunaan Asam Amino dan Ringer Laktat terhadap Penurunan Suhu Inti Pasien yang Menjalani Operasi Laparotomi Ginekologi dengan Anestesi Umum
}

\author{
Agung Hujjatulislam, ${ }^{1}$ Erwin Pradian, ${ }^{2}$ Ike Sri Redjeki ${ }^{2}$ \\ ${ }^{1}$ Rumah Sakit Umum Daerah Gunung Jati Cirebon, ${ }^{2}$ Departemen Anestesiologi dan Terapi intensif \\ Fakultas Kedokteran Universitas Padjadjaran/Rumah Sakit Dr. Hasan Sadikin Bandung
}

\begin{abstract}
Abstrak
Pemberian asam amino intravena merangsang metabolisme oksidatif sekitar $20 \%$ dan mengurangi komplikasi hipotermia pascaoperasi. Tujuan penelitian ini mengetahui efek penggunaan asam amino preoperatif terhadap suhu inti tubuh. Penelitian menggunakan metode kuantitatif intervensi dengan rancangan uji klinis acak terkontrol buta tunggal pada 40 orang pasien berusia 18-57 tahun dengan status fisik American Society of Anesthesiologists (ASA) I dan II yang menjalani operasi laparotomi ginekologi di Rumah Sakir Dr. Hasan Sadikin Bandung periode Febuari-Mei 2014. Subjek dibagi menjadi 2 kelompok secara acak, yaitu kelompok yang mendapat asam amino $2 \mathrm{~mL} / \mathrm{kgBB} / \mathrm{jam}$ selama 2 jam preoperasi dan kelompok kontrol yang mendapat infus Ringer laktat. Pencatatan suhu timpani dilakukan setiap 10 menit dari awal induksi hingga akhir anestesi. Data hasil penelitian diuji dengan Uji Mann-Whitney. Hasil penghitungan statistika, didapatkan suhu inti rata-rata selama anestesi pada kelompok asam amino bermakna lebih tinggi dibanding dengan kelompok kontrol $(p<0,05)$. Penurunan suhu rata-rata pada kelompok kontrol $\left(0,11^{\circ} \mathrm{C}\right)$ bermakna, lebih besar dibanding dengan kelompok asam amino $\left(0,08^{\circ} \mathrm{C} ; \mathrm{p}<0,05\right)$. Simpulan, pemberian cairan asam amino dua jam preoperasi dapat mencegah penurunan suhu yang lebih besar dibanding dengan kelompok kontrol selama operasi ginekologi laparotomi.
\end{abstract}

Kata kunci: Asam amino, hipotermia, suhu inti tubuh

\section{Comparison between Amino Acids and Ringer Lactate Infusion on Body Core Temperature Decline in Patients Undergo Gynaecological Laparotomy Surgery under General Anesthesia}

\begin{abstract}
Intravenous administration of amino acids stimulates about $20 \%$ oxidative metabolism and reduces postoperative complications of hypothermia. The aim of this study was to determine the effects of preoperative amino acid infusion to core temperature. This was an observational analytic study with crosssectional design to compare the reliability using the inter-rater reliability method. Subjects were 40 patients aged 18-57 years old with physical status ASA I and II who underwent gynaecological laparotomy at Dr. Hasan Sadikin General Hospital Bandung during February-May 2014. Subjects were devided randomly into 2 groups; one group was given $2 \mathrm{~mL} / \mathrm{kgBW} /$ hour amino acid infusion for 2 hours before laparotomy and another group was the control group given ringer lactate infusion. Tympani membrane temperature was taken every 10 minutes throughout the anesthetic procedure. Data were statistically analyzed using Mann-Whitney test.The result of this study was the average of core temperature during anesthesia in amino acid group was significantly higher than control group $(p<0.05)$. The average of temperature decline in the control group $\left(0.11^{\circ} \mathrm{C}\right)$ was significantly higher $(p<0.05)$ than the amino acid group $\left(0.08^{\circ} \mathrm{C}\right)$. This study concludes that amino acid infusion two hours before surgery will prevent greater decrease in temperature compared to the control group during gynecological laparotomy surgery.
\end{abstract}

Key words: Amino acids, body core temperature, hypothermia

Korespondensi: Agung Hujattulislam, dr., SpAn, Rumah Sakit Umum Daerah Gunung Jati Cirebon, Jl. Kesambi 56 Cirebon, Tlp 0231-206330, Mobile 081395299914, Email agung.hujjatulislam@gmail.com 


\section{Pendahuluan}

Pemeliharaan normotermia merupakan fungsi yang paling penting dari sistem saraf autonom. Disfungsi sel dan jaringan dapat terjadi apabila terjadi perubahan kecil suhu inti tubuh. Pada manusia, suhu inti tubuh dijaga dalam suhu $36,5-37,5^{\circ} \mathrm{C}$. Apabila terjadi perubahan suhu lingkungan, tubuh akan mempertahankan suhu dengan respons fisiologis dan juga perilaku. Ahli anestesi berperan dalam menghilangkan respons perilaku terhadap termoregulasi dan mungkin juga berperan dalam fungsi fisiologis termoregulasi tubuh. ${ }^{1}$

Dalam satu jam pertama pemberian anestesi akan terjadi penurunan pada suhu inti tubuh sebesar $0,5-1,5^{\circ} \mathrm{C}$. Mekanisme penurunan suhu selama anestesi adalah kehilangan panas pada kulit akibat dari proses radiasi, konveksi, konduksi, dan juga evaporasi yang lebih lanjut menyebabkan redistribusi dan penurunan laju metabolisme. Kehilangan kalor melalui kulit merupakan mekanisme yang paling dominan selama anestesi. ${ }^{2}$ Suhu inti tubuh perlahanlahan turun saat panas hilang dari permukaan kulit dan produksi panas melambat akibat penurunan metabolisme. ${ }^{3}$

Hipotermia didefinisikan keadaan suhu inti yang kurang dari $35^{\circ} \mathrm{C}$ dan merupakan suatu faktor risiko independen terjadinya mortalitas setelah trauma. ${ }^{4,5}$ Bila suhu kurang dari $36^{\circ} \mathrm{C}$ yang dipakai sebagai patokan maka insidensi hipotermia berkisar $50-70 \%$ dari seluruh pasien yang menjalani pembedahan dan $30 \%$ di antaranya dengan suhu $35^{\circ} \mathrm{C} .6,7$ Hipotermia merupakan komplikasi yang masih sering terjadi selama periode pembedahan, terutama di negara-negara yang berkembang karena kekurangan sarana untuk mempertahankan suhu pasien pada normotermia. ${ }^{6,8}$

Berbagai alat telah dikembangkan untuk mengurangi angka kejadian hipotermia. Alat ini dirancang untuk mengurangi kehilangan panas dari permukaan tubuh. Anestesi umum tidak hanya menyebabkan hipotermia dengan mengganggu regulasi panas tubuh, tetapi juga dengan menekan laju metabolisme oksidatif yang menghasilkan panas tubuh. Oleh karena itu, perhatian harus ditujukan untuk mencegah hipotermia yang disebabkan anestesi umum dengan menstimulasi produksi panas tubuh. ${ }^{9}$

Salah satu pencegahan hipotermia adalah teknik pemberian asam amino. ${ }^{10}$ Asam amino merupakan senyawa organik yang mempunyai gugus fungsional karboksil (-COOH) dan juga amina $\left(-\mathrm{NH}_{2}\right){ }^{11}$ Mekanisme asam amino dalam mencegah hipotermia belum diketahui secara pasti. Terdapat beberapa teori yang menjelaskan asam amino dalam mengurangi hipotermia. Asupan nutrisi, salah satunya ialah asam amino akan dicerna serta dimetabolisme untuk menghasilkan energi yang sebagian besar dalam bentuk panas. Asam amino dapat meningkatkan laju metabolik yang lebih tinggi dibanding dengan karbohidrat atau lemak. ${ }^{12}$ Pemberian asam amino, baik enteral maupun parenteral merangsang metabolisme oksidatif dan meningkatkan metabolisme sekitar 20\%. Metode ini telah dipergunakan untuk menjaga suhu tubuh intraoperatif dan juga mengurangi komplikasi hipotermia pascaoperasi. ${ }^{13}$

Pemberian asam amino dapat mengurangi penurunan suhu inti tubuh pada saat anestesi umum. ${ }^{12}$ Penelitian tentang pemberian infus asam amino perioperatif pada pasien yang dilakukan operasi histerektomi menunjukkan suhu inti tubuh menurun lebih kecil dibanding dengan kelompok kontrol. ${ }^{4}$ Pada penelitian lain, pemberian infus asam amino komposisi seimbang saat dua jam sebelum operasi pada pasien yang dilakukan anestesi umum, pada saat pasien bangun suhu inti tubuh $36,5 \pm 0,1^{\circ} \mathrm{C}$ pada kelompok asam amino serta $35,7 \pm 0,1^{\circ} \mathrm{C}$ pada kelompok kontrol. ${ }^{14}$ Penelitian tentang pemberian asam amino 2 jam sebelum operasi coronary arthery by-pass graft (CABG) dan kelompok kontrol dengan cairan $\mathrm{NaCl} 0,9 \%$, pada saat akhir operasi suhu inti tubuh $36,1^{\circ} \mathrm{C}$ pada kelompok asam amino dan $35,6^{\circ} \mathrm{C}$ pada kelompok kontrol. ${ }^{15}$ Pada penelitian pasien yang tidak dalam anestesi dengan pemberian asam amino $4 \mathrm{~J} / \mathrm{kgBB} / \mathrm{jam}$ selama 2,5 jam akan meningkatkan suhu tubuh $0,3 \pm 0,1^{\circ} \mathrm{C} .{ }^{13}$

Penelitian ini bertujuan untuk mengetahui penggunaan cairan infus asam amino dalam mencegah kejadian penurunan suhu inti tubuh pada pembedahan ginekologi dengan anestesi umum. 


\section{Subjek dan Metode}

Metode yang digunakan penelitian ini adalah kuantitatif intervensi dengan rancangan uji klinis acak terkontrol buta tunggal (single blind randomized controlled trial). Pengambilan sampel dengan metode consecutive admission (sesuai kedatangan pasien), sedangkan ukuran sampel ditentukan dengan cara menggunakan rumus besar sampel uji hipotesis dua rata-rata sehingga didapatkan jumlah subjek penelitian masing-masing kelompok minimal 20 pasien.

Penelitian ini dilakukan di Rumah Sakit Dr. Hasan Sadikin Bandung pada bulan FebruariMei 2014 terhadap perempuan yang menjalani operasi ginekologi laparotomi berusia 18-60 tahun dengan status fisik menurut American Society of Anesthesiologists (ASA) kelas I dan II. Kriteria eksklusi adalah pasien dengan suhu $>37,5^{\circ} \mathrm{C}$, obesitas/body mass index $(\mathrm{BMI} \geq 30)$ atau kurang gizi $(\mathrm{BMI}<18,5)$, pasien dengan hiponatremia, pasien dengan gangguan ginjal, dan gangguan hepar.

Setelah mendapat persetujuan dari Komite Etik Penelitian Kesehatan Fakultas Kedokteran Universitas Padjadjaran/Rumah Sakit Dr. Hasan Sadikin Bandung, dan penandatangan formulir persetujuan (informed consent) oleh pasien, dilakukan randomisasi menggunakan tabel bilangan random, sampel dibagi menjadi 2 (dua) kelompok, kelompok I (asam amino) dan kelompok II (kontrol) yang diukur suhu timpani masing-masing.

Pada kelompok I, pasien diberikan asam amino sebanyak $2 \mathrm{~mL} / \mathrm{kgBB} / \mathrm{jam}(4 \mathrm{~kJ} / \mathrm{kgBB} /$ jam) saat 2 jam menjelang induksi, sedangkan pada kelompok II diberikan cairan Ringer laktat $2 \mathrm{~mL} / \mathrm{kgBB} / \mathrm{jam}$ saat dua jam sebelum induksi sebagai kontrol. Suhu kamar operasi diatur pada temperatur $24^{\circ} \mathrm{C}$, pasien berbaring terlentang, dipasang alat monitor pemantauan suhu tubuh pasien dan dicatat data awal suhu timpani, laju nadi, EKG, dan juga saturasi. Selanjutnya, dilakukan induksi menggunakan

Tabel 1 Nilai Rata-rata, Simpangan Baku, Median, dan Rentang Karakteristik Dasar Subjek Penelitian pada Tiap Kelompok

\begin{tabular}{|c|c|c|c|}
\hline Karakteristik & $\begin{array}{c}\text { Asam Amino } \\
(n=20)\end{array}$ & $\begin{array}{c}\text { RL } \\
(n=20)\end{array}$ & Nilai p \\
\hline \multicolumn{4}{|l|}{ Usia (tahun) } \\
\hline Rata-rata (SD) & $38,85(11,06)$ & $39,55(9,26)$ & \multirow{2}{*}{0,829} \\
\hline Median (rentang) & $41,5(18-55)$ & $43(23-57)$ & \\
\hline \multicolumn{4}{|l|}{ Tinggi badan $(\mathrm{cm})$} \\
\hline Rata-rata (SD) & $151,8(5,14)$ & $150,8(4,87)$ & \multirow{2}{*}{0,602} \\
\hline Median (rentang) & $150(145-165)$ & $150(145-162)$ & \\
\hline \multicolumn{4}{|l|}{ Berat badan (kg) } \\
\hline Rata-rata (SD) & $55(8,68)$ & $51,9(7,41)$ & \multirow{2}{*}{0,253} \\
\hline Median (rentang) & $53,5(43-72)$ & $50(43-72)$ & \\
\hline \multicolumn{4}{|l|}{ Body mass index (BMI) } \\
\hline Rata-rata (SD) & $23,78(3,16)$ & $22,84(2,35)$ & \multirow{2}{*}{0,369} \\
\hline Median (rentang) & $24,05(19,1-28)$ & $23(20-27,5)$ & \\
\hline \multicolumn{4}{|c|}{ Suhu membran timpani $\left({ }^{\circ} \mathrm{C}\right)$} \\
\hline Rata-rata (SD) & $37,08(0,24)$ & $36,97(0,30)$ & \multirow{2}{*}{0,214} \\
\hline Median (rentang) & $37,15(36,6-37,5)$ & $37(36,5-37,5)$ & \\
\hline
\end{tabular}


Tabel 2 Nilai Derajat Penurunan Suhu Inti antara Kedua Kelompok Perlakuan

\begin{tabular}{|c|c|c|c|}
\hline \multirow{2}{*}{$\begin{array}{c}\text { Saat } \\
\text { Pengukuran } \\
\text { Suhu }\end{array}$} & \multicolumn{2}{|c|}{$\Delta T$} & \multirow[b]{2}{*}{$\mathbf{p}$} \\
\hline & $\begin{array}{c}\text { Asam } \\
\text { Amino } \\
(n=20)\end{array}$ & $\underset{(n=20)}{R L}$ & \\
\hline \multicolumn{4}{|l|}{$\mathrm{T}_{\text {sblm induksi }}$} \\
\hline $\mathrm{T}_{0}$ & $-0,20$ & $-0,37$ & 0,031 \\
\hline $\mathrm{T}_{10}$ & $-0,24$ & $-0,45$ & 0,009 \\
\hline $\mathrm{T}_{20}$ & $-0,06$ & $-0,24$ & 0,015 \\
\hline $\mathrm{T}_{30}$ & $-0,21$ & $-0,14$ & 0,041 \\
\hline $\mathrm{T}_{40}$ & $-0,08$ & $-0,20$ & 0,034 \\
\hline $\mathrm{T}_{50}$ & $-0,05$ & $-0,16$ & 0,033 \\
\hline $\mathrm{T}_{60}$ & $-0,08$ & $-0,01$ & 0,009 \\
\hline $\mathrm{T}_{70}$ & 0,02 & $-0,37$ & 0,024 \\
\hline $\mathrm{T}_{80}$ & $-0,05$ & 0,38 & 0,005 \\
\hline $\mathrm{T}_{90}$ & $-0,01$ & $-0,33$ & 0,025 \\
\hline $\mathrm{T}_{100}$ & 0,07 & $-0,53$ & 0,031 \\
\hline $\mathrm{T}_{110}$ & $-0,09$ & 0,90 & 0,000 \\
\hline $\mathrm{T}_{120}$ & $-0,01$ & $-0,44$ & 0,038 \\
\hline $\mathrm{T}_{130}$ & $-0,05$ & 0,33 & 0,095 \\
\hline $\mathrm{T}_{140}$ & 0,10 & 0,39 & 0,377 \\
\hline $\mathrm{T}_{150}$ & $-0,15$ & $-0,10$ & 0,571 \\
\hline $\mathrm{T}_{160}$ & $-0,10$ & 0,05 & 0,667 \\
\hline $\mathrm{T}_{170}$ & - & $-0,10$ & - \\
\hline $\mathrm{T}_{\text {rata-rata }}$ & $-0,08$ & $-0,11$ & 0,014 \\
\hline
\end{tabular}

Keterangan: $\mathrm{T}_{\text {sblmInduksi }}$ : sebelum induksi, $\mathrm{T}_{10}: 10$ menit, $\mathrm{T}_{20}: 20$ menit, $\mathrm{T}_{30}: 30$ menit, $\mathrm{T}_{40}: 40$ menit, $\mathrm{T}_{50}: 50$ menit, $\mathrm{T}_{60}: 60$ menit, $\mathrm{T}_{70}: 70$ menit, $\mathrm{T}_{80}: 80$ menit, $\mathrm{T}_{90}: 90$ menit, $\mathrm{T}_{100}: 100$ menit, $\mathrm{T}_{110}: 110$ menit, $\mathrm{T}_{120}: 120$ menit, $\mathrm{T}_{130}: 130$ menit, $\mathrm{T}_{140}: 140$ menit, $\mathrm{T}_{150}: 150$ menit, $\mathrm{T}_{160}: 160$ menit, $\mathrm{T}_{170}: 170$ menit, $\mathrm{t}: \mathrm{Uji} \mathrm{t}$ : bermakna $(p<0,05)$, Nilai $p$ dihitung berdasar atas uji t. $\Delta$ T:perubahan suhu

propofol $2 \mathrm{mg} / \mathrm{kgBB}$, fentanil $2 \mu \mathrm{g} / \mathrm{kgBB}$, serta atrakurium $0,5 \mathrm{mg} / \mathrm{kgBB}$ dan volatil isofluran, kemudian dilakukan intubasi.

Selama pembedahan berlangsung, anestesi dipertahankan menggunakan oksigen dalam $\mathrm{N}_{2} \mathrm{O} 60 \%$ dengan fresh gas flow $4 \mathrm{~L} /$ menit. Pernapasan dikontrol dengan volume tidal
$6 \mathrm{~mL} / \mathrm{kgBB}$ dan frekuensi pernapasan 12x/ menit. Perdarahan yang terjadi pada kelompok I dan II digantikan dengan cairan kristaloid hangat (suhu $37^{\circ} \mathrm{C}$ ) sebanyak tiga kali volume perdarahan dan jumlah cairan yang digunakan dicatat. Dicatat juga suhu kamar operasi, lama operasi, serta lama anestesi. Air cuci selama operasi menggunakan $\mathrm{NaCl}$ 0,9\% yang sudah dihangatkan di dalam lemari penghangat yang diatur pada suhu $37^{\circ} \mathrm{C}$ dan dicatat pula jumlah air cuci yang digunakan. Pada akhir operasi, semua kelompok dilakukan reversal dengan neostigmin $0,04 \mathrm{mg} / \mathrm{kgBB}$ dan sulfas atropin $0,02 \mathrm{mg} / \mathrm{kgBB}$.

Uji normalitas data numerik untuk melihat distribusi data yaitu data suhu inti dengan Uji Shapiro Wilks untuk besar sampel kurang dari 50 orang. Data berdistribusi normal bila nilai $p>0,05$. Analisis bivariabel untuk menguji suhu inti antara kelompok perlakuan dan kelompok kontrol digunakan Uji Mann-Whitney bila data tidak berdistribusi normal dan uji-t bila data berdistribusi normal. Analisis data dilakukan dengan memakai program statistical product and service solutions (SPSS) for windows versi 20.0 pada derajat kepercayaan $95 \%$ dengan nilai $\mathrm{p} \leq 0,05$.

\section{Hasil}

Penelitian dilakukan terhadap 40 pasien yang telah menjalani operasi ginekologi laparotomi dengan anestesi umum. Hasil analisis statistik menunjukkan bahwa karakteristik dasar pada kedua kelompok dinyatakan tidak berbeda secara bermakna ( $p>0,05$; Tabel 1$)$.

Suhu inti rata-rata pada kedua kelompok perlakuan menurun selama anestesi. Semua subjek penelitian mengalami penurunan suhu tubuh dengan derajat penurunanyang berbeda. Pada 120 menit pertama terjadi perbedaan penurunan suhu yang bermakna. Selanjutnya, perubahan suhu menjadi tidak bermakna sejak menit ke-130. Derajat penurunan suhu rata-rata pada kelompok asam amino sebesar $-0,08^{\circ} \mathrm{C}$, sedangkan kelompok RL mengalami penurunan suhu yang lebih kecil yakni sebesar $-0,11^{\circ} \mathrm{C}$ (Tabel 2). 
Tabel 3 Nilai Rata-rata, Simpangan Baku, Median, dan Rentang Variabel Perancu pada Subjek Penelitian Tiap Kelompok

\begin{tabular}{|c|c|c|c|}
\hline Karakteristik & $\begin{array}{c}\text { Asam Amino } \\
(n=20)\end{array}$ & $\begin{array}{c}\text { RL } \\
(n=20)\end{array}$ & Nilai p \\
\hline \multicolumn{4}{|l|}{ Lama operasi (menit) } \\
\hline Rata-rata (SD) & $122,9(15,38)$ & $127,4(18,68)$ & \multirow{2}{*}{0,411} \\
\hline Median (rentang) & $121(95-145)$ & $123,5(105-175)$ & \\
\hline \multicolumn{4}{|l|}{ Lama anestesi (menit) } \\
\hline Rata-rata (SD) & $130(15,89)$ & $134,5(18,77)$ & \multirow{2}{*}{0,418} \\
\hline Median (rentang) & $130(100-160)$ & $130(110-180)$ & \\
\hline \multicolumn{4}{|l|}{ Jumlah cairan (mL) } \\
\hline Rata-rata (SD) & $1875(217,34)$ & $1875(228,55)$ & \multirow{2}{*}{0,925} \\
\hline Median (rentang) & $2.000(1.500-2.200)$ & $2.000(1.500-2.200)$ & \\
\hline \multicolumn{4}{|l|}{ Suhu cairan $\left({ }^{\circ} \mathrm{C}\right)$} \\
\hline Rata-rata (SD) & $37,02(0,16)$ & $36,95(0,21)$ & \multirow{2}{*}{0,250} \\
\hline Median (rentang) & $37(36,8-37,3)$ & $36,95(36,5-37,3)$ & \\
\hline \multicolumn{4}{|l|}{ Suhu kamar operasi $\left({ }^{\circ} \mathrm{C}\right)$} \\
\hline Rata-rata (SD) & $24,05(0,08)$ & $24,07(0,09)$ & \multirow{2}{*}{0,478} \\
\hline Median (rentang) & $24(23,9-24,2)$ & $24,1(23,9-24,3)$ & \\
\hline \multicolumn{4}{|l|}{ Jumlah air cuci (mL) } \\
\hline Rata-rata (SD) & $1.495(245,38)$ & $1.535(122,58)$ & \multirow{2}{*}{0,211} \\
\hline Median (rentang) & $1.500(1.000-2.000)$ & $1.500(1.400-1.800)$ & \\
\hline \multicolumn{4}{|l|}{ Suhu air cuci $\left({ }^{\circ} \mathrm{C}\right)$} \\
\hline Rata-rata (SD) & $37,01(0,16)$ & $37(0,18)$ & \multirow{2}{*}{0,852} \\
\hline Median (rentang) & $37(36,8-37,3)$ & $37(36,7-37,3)$ & \\
\hline \multicolumn{4}{|l|}{ Jumlah perdarahan (mL) } \\
\hline Rata-rata (SD) & $425(76,95)$ & $415(81,27)$ & \multirow{2}{*}{0,738} \\
\hline Median (rentang) & $425(300-500)$ & $400(300-500)$ & \\
\hline
\end{tabular}

Keterangan: *Perbedaan bermakna jika p<0,05. Nilai p variabel suhu air cuci dan lama anestesi dihitung berdasarkan uji-t, sedangkan nilai p variabel lainnya dihitung berdasarkan Uji Mann-Whitney dikarenakan salah satu kelompok data tidak berdistribusi normal. SD : simpangan baku

Data-data variabel perancu selama operasi yaitu jumlah cairan, suhu ruangan, suhu membran timpani, jumlah perdarahan, jumlah cairan, jumlah air cuci, dan juga lama anestesi menunjukkan bahwa semua karakteristik pada kedua kelompok dinyatakan tidak berbeda bermakna secara statistika ( $p>0,05$; Tabel 3).

Tidak terdapat subjek penelitian yang mendapatkan transfusi darah selama operasi. Tidak ditemukan komplikasi atau efek samping serius lain selama penelitian dilakukan.

\section{Pembahasan}

Perbandingan karakteristik kedua kelompok perlakuan tidak menunjukkan perbedaan yang bermakna $(p>0,05)$ sehingga subjek penelitian dianggap telah homogen dan juga layak untuk dibandingkan (Tabel 1). Tidak terdapat subjek penelitian yang dikeluarkan selama penelitian ini berlangsung.

Terjadi perbedaan penurunan suhu yang bermakna pada saat 120 menit pertama 
(Tabel 2). Selanjutnya, perubahan suhu inti menjadi tidak bermakna sejak menit ke-130, keadaan ini disebabkan karena saat tersebut peritoneum sudah ditutup serta perdarahan yang minimal sehingga penggantian cairan pun menjadi sangat minimal, akibatnya perbedaan perubahan suhu inti menjadi tidak bermakna. Pada kelompok kontrol $\left(0,11^{\circ} \mathrm{C}\right)$ lebih besar dibanding dengan kelompok asam amino $\left(0,08^{\circ} \mathrm{C}\right)$ dengan perbedaan yang bermakna $(p<0,05)$. Penelitian lain menunjukkan bahwa penurunan suhu rata-rata pada kelompok kontrol $\left(0,13^{\circ} \mathrm{C}\right)$ lebih besar dibandingkan dengan kelompok asam amino $\left(0,08^{\circ} \mathrm{C}\right)$ dan perbedaannya bermakna. ${ }^{4}$ Penurunan suhu pada kelompok asam amino lebih minimal dibanding dengan kontrol. Kondisi ini terjadi karena pemberian asam amino $2 \mathrm{~mL} / \mathrm{kgBB} /$ jam sebelum operasi akan meningkatkan kadar panas jaringan perifer, dengan demikian akan menurunkan redistribusi panas dari inti tubuh ke jaringan perifer setelah induksi anestesi. Proses redistribusi sangat bergantung pada besarnya gradien antara suhu inti dan perifer (permukaan kulit). Semakin sempit gradien antara suhu inti dan suhu perifer tubuh maka semakin kecil proses redistribusi.

Teknik anestesi umum dapat memengaruhi ketiga elemen termoregulasi yang meliputi input aferen, pemrosesan sinyal di pusat, dan respons eferen. Anestesi umum menggeser batas ambang untuk respons vasokonstriksi, menggigil, vasodilatasi, dan juga berkeringat. Semua obat-obat anestesi umum memengaruhi termoregulasi dengan derajat hampir sama. ${ }^{1}$

Dari penelitian ini, terlihat bahwa tindakan pemberian asam amino dua jam preoperasi bersifat memperlambat penurunan suhu inti tubuh. Selain itu, kelompok asam amino tidak mengalami hipotermia selama berlangsungnya pembedahan sehingga dapat dikatakan bahwa pemberian infus asam amino $2 \mathrm{~mL} / \mathrm{kgBB} / \mathrm{jam}$ selama dua jam preoperasi dapat mencegah hipotermia selama operasi.

Data-data variabel perancu selama operasi yaitu jumlah cairan infus, suhu ruangan, suhu membran timpani, jumlah perdarahan, jumlah air cuci, serta lamanya anestesi menunjukkan bahwa seluruh karakteristik pada kedua kelompok dinyatakan tidak berbeda bermakna secara statistika $(p>0,05)$ sehingga data kedua kelompok layak untuk diperbandingkan (Tabel $3)$.

Tidak terdapat subjek penelitian yang mendapatkan transfusi darah selama operasi sehingga cairan yang diberikan selama operasi hanya berdasarkan perhitungan penggantian defisit cairan puasa. Pemberian asam amino dengan infusion pump kecepatan $2 \mathrm{~mL} / \mathrm{kgBB} /$ jam kemudian dilakukan monitoring ketat, tidak ditemukan komplikasi atau efek samping serius lain selama penelitian.

Proses kehilangan suhu tubuh dapat terjadi melalui beberapa mekanisme, yaitu radiasi, evaporasi, konduksi, dan konveksi. Radiasi merupakan kontributor yang terbesar (60\%) dalam proses perpindahan panas tubuh ke lingkungan. ${ }^{2}$ Sebanyak 20-27\% kehilangan kalor terjadi dengan cara evaporasi. Mekanisme ini terjadi pada bagian tubuh manusia yang basah atau lembab, yaitu mukosa, permukaan kulit yang lembab, dan juga paru-paru. Bagian tubuh pasien yang tidak ditutupi kain dalam penelitian ini adalah wajah, tangan tempat pemasangan infus, probe saturasi, dan daerah operasi. Pada bagian yang tidak ditutupi ini, semua mekanisme perpindahan panas dapat terjadi. ${ }^{2,16}$

Konduksi merupakan proses perpindahan panas secara langsung antara 2 (dua) materi padat yang berhubungan langsung tanpa ada transfer panas molekul. Panas menjalar dari bagian yang memiliki suhu tinggi ke bagian dengan suhu yang lebih rendah. Besarnya kalor yang hilang melalui proses ini bergantung pada faktor perbedaan suhu antara kulit dan benda padat yang menempel. Konduktivitas dengan kulit dapat mengakibatkan proses konduksi, terutama bila suhu benda tersebut berbeda jauh di bawah suhu permukaan kulit. Kain alas tempat tidur dan kain steril penutup pasien yang basah karena darah atau cairan irigasi dapat memperbesar derajat konduksi. Pada penelitian ini, proses pelepasan panas tubuh secara konduksi masih tetap terjadi..,16

Konveksi adalah suatu perambatan panas melalui aliran cairan/gas. Besarnya konveksi bergantung pada luas kontak dan perbedaan 
suhu. Proses seperti ini dipengaruhi oleh suhu permukaan kulit, suhu udara, luas permukaan kulit, serta kecepatan gerak udara di sekitar kulit. Kehilangan panas dengan cara ini kirakira mencapai 32\%. ${ }^{2,16}$ Pada penelitian ini, hampir seluruh tubuh pasien tertutup dengan kain sehingga kehilangan panas tubuh melalui konveksi dapat diminimalisasi.

Pada penelitian ini terdapat keterbatasan, yaitu peneliti tidak memeriksa kadar albumin serta protein total pasien sebagai penanda status gizi pasien yang berhubungan dengan proses metabolisme asam amino dikarenakan keterbatasan dana penelitian.

\section{Simpulan}

Pemberian asam amino dua jam preoperasi dapat mencegah penurunan suhu yang lebih besar selama operasi laparotomi ginekologi dibanding dengan pemberian Ringer laktat.

\section{Daftar Pustaka}

1. Buggy DJ, Crossley AW. Thermoregulation, mild hypothermia and post anaesthetic shivering. Br J Anaesth. 2000;84:615-28.

2. Stoelting RK, Hillier SC, penyunting. Thermoregulation. Edisi ke-4.Philadelphia: Lippincott Williams and Wilkins; 2006.

3. Ando S, Kanazawa M, Tsuda M, Suzuki T. Effects of intravenous amino acids on anesthesia-induced hypothermia in ovariectomized rats. J Nutr Sci Vitaminol. 2012;58:143-8.

4. Sellden E, Sten G, Lindahl E. Amino acid induced thermogenesis reduces hypothermia during ansthesia and shortens hospital stay. Anesth Analg. 1999; 89:1551-6.

5. Avellanas ML,RicartA,Vidal M.Management of severe accidental hypothermia. Med Intensiva. 2012;36(3):200-12.

6. Zhou P, Ge S, Xue Z. Novamin infusion: a new method to cure postoperative shivering with hypothermia. J Surg Research. 2014;188:69-76.
7. Shao L, Zheng H, Wen H. Methods of patient warming during abdominal surgery. J $P$ One. 2012;7(7):1-7.

8. Sessler DI. Temperature regulation and monitoring. Dalam: Miller RD, penyunting. Miller's anesthesia. Edisi ke-7. Philadelphia: Elsevier Churchill Livingston; 2009. hlm. 1533-56.

9. Sellden E, Branstorm R, Brundin T. Preoperative infusion of amino acids prevents post operative hypothermia. Br J Anaesth. 1996;76:227-34.

10. Kurz A, Sessler ID. Perioperative normothermia to reduce the incidence of surgical wound infection and shorten hopitalization. N Engl J Med. 1996;334: 1209-15.

11. Lieberman M, Marks AD, Smith C. Amino acids and protein. Dalam: Lieberman M, penyunting. Mark's essential medical biochemistry. Edisi ke-2. Philadelphia: Lippincott Williams \& Wilkins. 2007. hlm. 50-61.

12. Gupta N, Sehgal R, Agrawal N. A prospective randomized double blind study to evaluate the effect of infusion amino acid enriched solution on recovery from neuromuscular blockade. Ind J Anaesth. 2009;53(3):318-23.

13. Nakajima Y, Takamata A, Matsukawa T. Effect of amino acid infusion on central thermoregulatory control in humans. Anesthesiology. 2004;100:634-9.

14. Sellden E, Sten G, Lindahl E. postoperative nitrogen ekskretion after amino acid induced thermogenesis under general anesthesia. Anesth Analg. 1998;87:641-6.

15. Umenai T, Nakajima Y. periopertative amino acid infusion improves recovery and shortens the uration of hospitalization after off-pump coronary artery bypass grafting. Anasth Analg. 2006;103:1386-93.

16. Diaz M, Becker DE. Thermoregulation: physiological and clinical considerations during sedation and general anesthesia. Anesth Prog. 2010;57:25-33. 